American Journal of Applied Sciences 8 (9): 878-883, 2011

ISSN 1546-9239

(C) 2011 Science Publications

\title{
Women Empowerment through Participation in Microcredit Programme: A Case Study
}

\author{
${ }^{1}$ Ferdoushi Ahmed, ${ }^{1}$ Chamhuri Siwar and ${ }^{2}$ Nor Aini Hj. Idris \\ ${ }^{1}$ Institute for Environment and Development (LESTARI), \\ ${ }^{2}$ Economics Study Centre, Faculty of Economics and Management, \\ University Kebangsaan Malaysia, 43600, UKM, Bangi, Selangor D.E., Malaysia
}

\begin{abstract}
Problem statement: Although women constitute almost half of the total population of Bangladesh, they are ascribed a lower status than men. Especially, rural women in Bangladesh experience adverse situations in terms of socio-economic inequality and gender disparity. They are the most deprived of the society and majority of them are extremely poor. Microcredit programme contributes to increase empowerment of rural women in Bangladesh. Approach: This study examines the extent of empowerment creation of rural women through involvement in microcredit programme in Bangladesh. The study is based on empirical data collected through interview from the two groups of rural women e.g., 'with credit' and 'without credit' rural women. The 'with credit' respondent represents the rural women who have taken loan from the Grammeen Bank's microcredit programme. Results: The findings show that majority $(84 \%)$ of the 'with credit' respondents are more empowered in terms of family decision making matters compared (76\%) to the 'without credit' respondent. Conclusion: It is concluded that 'with credit' rural women have enhanced their empowerment by participating microcredit programmes of Grameen Bank Bangladesh.
\end{abstract}

Key words: Rural women, women empowerment, microcredit programme, self-sufficient, poverty alleviation, household items, microcredit programme, Empowerment Index (EI), Statistical Package for Social Science (SPSS)

\section{INTRODUCTION}

The empowerment of women is one of the central issues in the process of development of all developing countries in the world (Hoque and Itohara, 2009). Bangladesh is a least developing country and women constitute almost half of its total population of which $80 \%$ live in rural areas (BPB, 2006). Rural women in Bangladesh have a lower socio-economic status and very limited access to income generating activities due to a number of social, cultural and religious barriers. Women are not only socially discriminated, but also are subject to threat, exploitation and harassment of all sorts (Sarker and Rahman, 2007). Traditionally, women in Bangladesh have lower status, as compared to men in every sphere of socio-economic and political life. Rural women have very limited access in economic and social activities. In this situation, microcredit programme has emerged as an important financial instrument to women empowerment and poverty alleviation, especially in rural areas of Bangladesh. Under microcredit programme, MFIs provide small loans to the very poor in order to undertake self-employment and other financial and business activities giving them the ability to care for themselves and their families and thus, achieve a level of self-sufficient.

Women empowerment is other most significant purpose of microcredit programmes. Participation of rural women in microcredit programme has increased their mobility in the markets to buy necessary goods and services for home, in medical centers to get treatment facilities for the household members, in cinema hall to watch movie and in neighbor and relative's house within and outside the village to strengthen relationship (Afrin et al., 2008). Ware (2007) revealed that microcredit programme enhances their voices in determining their relations with the world outside home in terms of their mobility, involvement in trade and wage labour and participation in public spheres. Ahmed et al. (2011) also found that borrower women of Grameen Bank contribute 19\%, on an average, of their total family income while the nonborrower women $10 \%$ of their total family income. Therefore, microcredit is contributing to some extent in

Corresponding Author: Ferdoushi Ahmed, Institute for Environment and Development (LESTARI), University Kebangsaan Malaysia, 43600, UKM, Bangi, Selangor D.E., Malaysia Tel: +60143626210 Fax: +603-89255104 
generating economic activities and participation in family decision making of the rural women (Hoque and Itohara, 2008). It also has been regarded as one of crucial tools for poverty reduction and women's empowerment (AL-Amin and Chowdhury, 2008).

This study shows how microcredit programme contributes to increasing empowerment of 'with credit' rural women. The study also compares women empowerment about family decision making regarding their household matters between 'with credit' and 'without credit' rural women.

\section{MATERIALS AND METHODS}

Survey design, sampling method, data collection and data analysis: Deriving accurate information is highly dependent upon the survey method. The direct face-toface interview is the most commonly used approach (Ogunlade and Adebayo, 2009) and is employed in this study. The data for this study is taken to reflect the objectives of the study. Data was collected through interview from the selected samples of Pachagarh Districts with two groups ('with credit' and 'without credit') of rural women. In this study, sampling design was followed by "random sampling" method. In the first stage of the survey and sampling, the study was purposively selected the samples of the rural women in the Panchagarh District. Then, the samples were divided into two groups (i) 'with credit' and (ii) 'without credit' rural women. Grameen Bank members are chosen for 'with credit' respondents. For the 'with credit' samples, this study has selected 200 samples randomly from the listed (about 700) rural women of Grameen Bank members in the Pokhi Laga, Vetor gor, Chand para and Madhuban guchchho gram. For the 'without credit' samples, this study has selected 100 samples randomly from the total rural women (900) from the Goual para and Jamader para villages, who do not bear loan or credit. The data were collected by the researcher herself and the period was from1st April 2008 to 30 June 2008.

After survey of the study, all the data were coded directly on questionnaires and then entered into personal computer. Several analyses of the data have been carried out in the core of this study. Simple descriptive statistics such as sums, means, percentages, frequency distributions and crosstabulations are were used to analysis primary data for this study. This study utilised the Statistical Package for Social Science (SPSS) to analyse the data. This study also employed Empowerment Index (EI) to determine the level of empowerment of 'with credit' and 'without credit' rural women.

This study employed Empowerment Index (EI) to assess the level of empowerment of 'with credit' and 'without credit' rural women in terms of decision making of household matters. EI was adopted from the study conducted. They calculated Participation Index (PI) to assess the status of freedom the rural women enjoy in decision making of various family matters. In measuring PI, they took into account the level of participation of borrower women and non-borrower women in decision making of important matters for the family. This study considered the following decision making variables to assess the level of empowerment the respondents enjoy within their family.

- Empowerment in decision making for ability to spend your own income

- Empowerment in decision making for maintenance of family expenditures

- Empowerment in decision making for ability to spend husband and son's income.

- Empowerment in decision making for buying and selling of real estate

- Empowerment in decision making for regarding crop production

- Empowerment in decision making for rearing livestock (poultry and dairy)

- Empowerment in decision making for regarding social ceremony or visiting relatives house

- Empowerment in decision making for borrowing loan

- Empowerment in decision making for family planning matters

- Empowerment in decision making for alopathy medical treatment

- Empowerment in decision making for marriage of sons and daughters

- Empowerment in decision making regarding education of sons and daughters

- Empowerment in decision making for regarding homestead gardening

- Empowerment in decision making for caring children

A three point scale was used to assess the empowerment of 'with credit' and 'without credit' women in the fourteen selected decision variables. The scores given for different levels of empowerment in decision making are 1 , if other members of the family take the decision; 2, if the decision is taken by husband alone; 3 , if the decision is taken by the respondent 
(yours) alone. The Empowerment Index (EI) was calculated by using the following way.

Empowerment Index (EI) for each decision making matter:

$$
\mathrm{EI}_{\mathrm{i}}=\mathrm{E}_{\mathrm{op}} \mathrm{X}_{1}+\mathrm{E}_{\mathrm{hp}} \mathrm{X}_{2}+\mathrm{E}_{\mathrm{sp}} \mathrm{X}_{3}
$$

Where:

$\mathrm{EI}_{\mathrm{i}}=$ Empowerment Index of the each decision making matter

$\mathrm{E}_{\mathrm{OE}}=$ Percentage of respondents where decisions are taken by others

$\mathrm{E}_{\mathrm{hE}}=$ Percentage of respondents where decisions are taken by respondent's husband.

$\mathrm{E}_{\mathrm{sE}}=$ Percentage of respondents where decisions are taken by respondent's herself

The overall empowerment index is calculated as follows:

$$
\mathrm{EI}=\frac{\mathrm{Z}_{1} \mathrm{EI} 1+\mathrm{Z}_{2} \mathrm{EI} 2+\mathrm{Z}_{3} \mathrm{EI} 3}{\mathrm{Z}_{1}+\mathrm{Z}_{2}+\mathrm{Z}_{3}}=\frac{\sum_{\mathrm{i}=0}^{3} \mathrm{ZiEi}}{\sum_{\mathrm{i}=0}^{3} \mathrm{Zi}}
$$

Where:

$\mathrm{EI}_{1} \quad=$ Total score where decisions are taken by others

$\mathrm{EI}_{2} \quad=$ Total score where decisions are taken by respondent's husband

$\mathrm{EI}_{3} \quad=$ Total score where decisions are taken by respondent herself

$\mathrm{Z}_{1}, \mathrm{Z}_{2}$ and $\mathrm{Z}_{3}=$ The number of responses for each decision making matters

Empowerment Index for each selected decision making matters has been considered as a proxy for freedom which could range from 1-300; where 1 indicating no freedom of the respondent and 300 indicating perfect (full) freedom. For clear understanding, the empowerment index was converted in to percentage using the maximum possible empowerment index of 300 as $100 \%$.

\section{RESULTS AND DISCUSSION}

Empowerment of 'with credit' and 'without credit' rural women: In Bangladesh the women feel deprived in every sphere of their lives. Right from their birth, women are neglected in food sharing, education, work, independent thinking, right to property, choice and matters of decision making (Islam and Sultana, 2006). So, women have very little empowerment or are often very less concerned in the decision making process even at the household level activities. In this study, attempts was made to analyses the pattern of empowerment of 'with credit' and 'without credit' rural women in decision making matters of the family. The aspect of women's status of freedom in decision making was measured by empowerment index. In order to measure the extent of empowerment in the decision making activities of household 14 variables were considered (Table 1). Responses to questions of household decision making were coded 3 categories as defined below:

- "Decision taken by self" implies that decisions are made by the respondents themselves

- "Decision taken by the husband" are those decisions where the respondents have no say and when the respondent's husband determines the matters all by himself without any participation of the respondent and in such decisions, the husbands opinion is essentially imposed upon the respondent

- "Decision taken by other members of the family" are those decisions made only by the other members with the exclusion of both the husband and the respondent. In such decision making processes, neither her husband nor the respondent participate

In this study, decision making level has been measured by the percentage of empowerment of 'With Credit' (WC) and 'Without Credit' (WOC) rural women in the decision making process of family. Level of empowerment has been calculated from three different scores given in terms of who takes decision. For example, 1 score was recorded if the decision is taken by other members of the family. A score of 2, if taken by husband and score of 3 , if taken by the respondent herself. Table 1 shows the Empowerment Index (EI) and Percentage Of Empowerment (POE) for each respondent.

Table 1 reveals that, when the decision is taken by anybody other than respondent and her husband, the EI is 100 and POE is $33.33 \%$.

\begin{tabular}{|c|c|c|}
\hline Responses & $\begin{array}{l}\text { Empowerment } \\
\text { Index }(E I)\end{array}$ & $\begin{array}{l}\text { Percentage of } \\
\text { empowerment (POE) }\end{array}$ \\
\hline & 3 & 300 \\
\hline $\begin{array}{l}\text { Self } \\
\text { (respondent) }\end{array}$ & $\begin{array}{l}\text { EI }=----- \text { x } 100=300 \\
3\end{array}$ & $\begin{array}{l}\text { POE }=----\quad \times 100=100 \\
300\end{array}$ \\
\hline & 2 & 200 \\
\hline Husband & $\begin{array}{l}\text { EI }=----\times 100=200 \\
2\end{array}$ & $\begin{array}{l}\text { POE }=------ \text { x } 100=66.66 \\
300\end{array}$ \\
\hline Others & $\begin{array}{l}1 \\
E I=---x \quad 100=100 \\
1\end{array}$ & $\begin{array}{l}100 \\
\text { POE }=------- \text { x } 100=33.33 \\
300\end{array}$ \\
\hline
\end{tabular}

Table 1: Empowerment index and percentage of empowerment 
Am. J. Applied Sci., 8 (9): 878-883, 2011

Table 2: Empowerment index of 'with credit' and 'without credit' rural women in decision making matters

\begin{tabular}{|c|c|c|c|c|c|c|c|c|c|c|}
\hline \multirow[b]{2}{*}{ Decision making matters } & \multicolumn{5}{|c|}{$\begin{array}{l}\text { With credit group } \\
\text { Degree of empowerment (No. of responses) }\end{array}$} & \multicolumn{5}{|c|}{$\begin{array}{l}\text { Without credit group } \\
\text { Degree of empowerment (No. of responses) }\end{array}$} \\
\hline & Self & Husband & Others & $\begin{array}{l}\text { Empower } \\
\text { ment Index } \\
\text { (EI) }\end{array}$ & $\begin{array}{l}\% \text { of } \\
\text { empower } \\
\text { ment }\end{array}$ & Self & Husband & Others & $\begin{array}{l}\text { Empower } \\
\text { ment Index } \\
\text { (EI) }\end{array}$ & $\begin{array}{l}\% \text { of } \\
\text { empower } \\
\text { ment }\end{array}$ \\
\hline Ability to spend your own income & 106 & 94 & & 253.00 & 84.33 & 33 & 63 & 4 & 229.00 & 76.33 \\
\hline Maintenance of family expenditures & 120 & 64 & 16 & 252.00 & 84.00 & 43 & 52 & 5 & 238.00 & 79.33 \\
\hline Ability to spend husband and son's Income & 90 & 92 & 18 & 236.00 & 78.66 & 34 & 43 & 23 & 211.00 & 70.33 \\
\hline Buying and selling of real estate & 86 & 102 & 12 & 237.00 & 79.00 & 31 & 41 & 28 & 203.00 & 67.66 \\
\hline Regarding crop production & 100 & 84 & 16 & 242.00 & 80.66 & 30 & 39 & 31 & 199.00 & 66.33 \\
\hline Rearing livestock (poultry ans dairy) & 90 & 98 & 12 & 239.00 & 79.66 & 34 & 45 & 21 & 213.00 & 71.00 \\
\hline Regarding social ceremony or visiting relatives house & 98 & 83 & 19 & 239.50 & 79.83 & 45 & 44 & 11 & 234.00 & 78.00 \\
\hline Borrowing loan & 114 & 74 & 12 & 251.00 & 83.66 & 43 & 50 & 7 & 236.00 & 78.66 \\
\hline Family planning matters & 108 & 92 & & 254.00 & 84.66 & 45 & 50 & 5 & 240.00 & 80.00 \\
\hline Alopathy medical treatment & 102 & 83 & 15 & 243.50 & 81.16 & 39 & 56 & 5 & 234.00 & 78.00 \\
\hline Marriage of sons and daughters: & 107 & 83 & 10 & 248.50 & 82.83 & 42 & 50 & 8 & 234.00 & 78.00 \\
\hline Regarding education sons and daughters & 116 & 66 & 18 & 249.00 & 83.00 & 47 & 45 & 8 & 239.00 & 79.66 \\
\hline Regarding homestead gardening & 200 & - & - & 300.00 & 100.00 & 44 & 50 & 6 & 238.00 & 79.33 \\
\hline Caring children & 200 & - & - & 300.00 & 100.00 & 57 & 36 & 7 & 250.00 & 83.33 \\
\hline All decision matters & 1637 & 1015 & 148 & 253.18 & 84.39 & 567 & 664 & 169 & 228.42 & 76.14 \\
\hline
\end{tabular}

Source: Field survey, 2008

Likewise when decision is taken by the husband of the respondent, the EI is 200 and the POE is $66.66 \%$. And when family matters are decided solely by the respondent herself, the EI is 300 and the POE is $100 \%$.

It is to be mentioned that Empowerment Index (EI) and Percentage Of Empowerment (POE) is positively related. If the EI increases and gets closer to 300, the percentage of empowerment approaches 100 .

the EI gets closer to 300 and POE to 100 it implies that status of women's decision making is very high and $100 \%$ POE indicates women takes all the decision alone.

Table 2 reveals that the POE in the ability to spend your own income was estimated to be about $84 \%$ for 'with credit' and about $76 \%$ for the 'without credit' rural women who indicate that respondent has some involvement and the decision is mostly taken than husband. As for individual empowerment of WC women, decision making on ability to spend your own income was taken by 106 respondents, 94 husbands and 0 other family members. On the other hand, decision to spend your own income of the WOC women was reported to have taken by 33 respondents, 63 husbands and 4 other family members. These indicate that $53 \%$ of the WC and $33 \%$ of the WOC women have the full freedom to decide for ability to spend your own income.

The POE on matters like maintenance of family expenditures and ability to spend husband and son's income, were 84 and about $79 \%$ respectively for WC respondents were about 79 and about $70 \%$ for WOC respondent. These imply that women have a good degree of freedom in these matters and the WC respondents were observed to have higher POE in these areas as compared to WOC respondents.
Concerning decision on buying and selling of real estate, POE were about 79 for $\mathrm{WC}$ respondents and about 68 for WOC women implying that the decision mainly lies with the herself (respondent). The EOP were estimated at about $81 \%$ and about $66 \%$ for the WC and WOC women respectively regarding the decision on types of crops to produce. WC women had a POE of about $80 \%$ for rearing livestock and poultry. The same for WOC women was $71 \%$. Both imply that the decision is mainly taken by herself.

Involvement of WC women in social ceremonies and visiting relative's house showed a POE of about $80 \%$ whereas it was found to be $78 \%$ for WOC women. This also means that WC sample have more freedom in this matter than the WOC women. Regarding decision making on borrowing money, $\mathrm{POE}$ of WC women was about $84 \%$ while it was about $79 \%$ for the WOC women indicating that both husband and wife have empowerment in this decision.

As far as family planning matter is concerned extent of empowerment of both WC (85\%) and WOC about $(80 \%)$ women was not so different. Thus, it appears that notso much difference exists regarding decision on family planning matters. Eight five and eighty WC and WOC women took their decisions independently. The POE of the WC sample involved in Grameen Bank was about about $81 \%$ as compared to $78 \%$ for WOC sample for decision on allopathic medical treatment.

The POE on matters like marriage of sons and daughters and education of sons and daughters, were about 83 and $83 \%$ respectively for WC respondents and 78 and about $80 \%$ for WOC respondent. These imply that women have a good degree of freedom in 
these matters in the sense that the decisions are taken jointly by the husband and respondent. The WC respondents were observed to have higher POE in these areas as compared to WOC respondents indicating that they are better off in the family decision making as compared to the WOC samples.

Table 2 reveals that decision making matters regarding homestead gardening and caring children both WC and WOC women were observed to have full freedom (100\% POE in case of WC women and about 79 and $83 \%$ in case of WOC women). The relatively high level of freedom in matters like homestead gardening and caring children may be due to the nature of the job which are usually done by women in rural areas. Considering all the decision making matters of the family it was observed that WOC sample had lower freedom (POE being 76.14\%) than WC women (POE being $84.39 \%$ ).

Therefore, 'with credit' women were observed to have enjoyed relatively more freedom and played important role in decision making matters of household than that of WOC women. However, the results of this analysis do conform of this study's sec hypothesis. This was perhaps, due to their involvement in Grameen Bank, training, skill development. which gradually enhanced their management ability, invigorates their self-confidence and ultimately upgraded their decision making capabilities.

Percentage of empowerment in decision making of 'with credit' and 'without credit' women: Table 3 shows extent of empowerment of 'with credit' and 'without credit' respondent according to the decision making level represented by percentage of empowerment (considering these decision making matters which were shown in Table 2). Table 3 reveals that 33.33 percent POE indicates that the decisions are taken by members of the family other than respondent and her husband. There are $5.29 \% \mathrm{WC}$ women and $12.07 \%$ WOC women with whom decision are taken by other members of the family.

Table 3: Empowerment in decision making of 'with credit' and 'without credit' sample

\begin{tabular}{lllll}
\hline & With credit & & Without credit \\
Percent of & ----- & ---- & $(\%)$ \\
Empowerment & No. & $(\%)$ & No. & 40.5 \\
\hline 100 & 1637 & 58.46 & 567 & 47.43 \\
66.66 & 1015 & 36.25 & 664 & 12.07 \\
33.33 & 148 & 5.29 & 169 & 100.0 \\
All samples & 2800 & 100 & 1400 &
\end{tabular}

At $66.66 \%$ POE, respondent's husband had the absolute right to take decision about the family matters. In case of $36.25 \%$ of WC and $47.43 \%$ of WOC samples, families decisions are entirely taken by husband alone disregarding wife and other members of the family. When the decision making level is $100 \%$, respondents alone decides about the family matters indicating that wives enjoy full freedom about family matters. About 58\% WC and about 40\% WOC respondents have the full freedom to decide about the decision making matters.

\section{CONCLUSION}

This study concludes that majority of the 'with credit' respondents showed higher of their empowerment of family decision making matters compared to the 'without credit' respondent. This study also determined that results of the analysis on status of freedom show that percentage of empowerment was about $84 \%$ for 'with credit' samples and about $76 \%$ for 'without credit' samples. The higher percentage of empowerment of the 'with credit' women imply that they enjoyed relatively more freedom and played important role in decision making matters of the household as compared to the 'without credit' women. This might have been due to their involvement in Grameen Bank training, skill development. The study concludes that Grameen Banks microcredit programme shows its potentiality to increase empowerment of rural women through initiated group dynamics and skill development training, women's education, adequate and timely availability of credit for income generating and productive activities among rural women in Bangladesh.

\section{ACKNOWLEDGEMENT}

This study is supported from the Commonwealth Scholarship and Fellowship Plan (CSFP) provided by Ministry of Higher Education, Malaysia. We are thankful to the International Programme Department of Grameen Bank for their kind permission to carry out the field works in the study areas. We are also thankful to the Manager, Grameen Bank, Satmera Branch in Panchagarh District, Bangladesh for his much needed cooperation in collecting data from the respondents. We are really grateful to all the respondents for providing valuable information and data. 


\section{REFERENCES}

Afrin, S., N. Islam and S.U. Ahmed, 2008. A multivariate model of micro credit and rural women entrepreneurship development in Bangladesh. Int. J. Bus. Manage., 3: 169-185.

Ahmed, F., C. Siwar and N.A.H. Idris, 2011. Contribution of rural women to family income through participation in microcredit: Empirical analysis. Am. J. Applied Sci., 8: 238-245. DOI: 10.3844/ajassp.2011,238.245

Al-Amin, M.D. and T. Chowdhury, 2008. Women, poverty and empowerment: An investigation into the dark side of microfinance. Asian Affairs, 30: 16-29.

BPB, 2006. Statistical Yearbook of Bangladesh. 1st Edn., Bangladesh Bureau of Statistics, Statistics Division, Ministry of Planning, Govt. of the People's Republic of Bangladesh, Bangladesh.

Hoque, M. and Y. Itohara, 2008. Participation and decision making role of rural women in economic activities: A comparative study for members and non-members of the micro-credit organizations in Bangladesh. J. Soc. Sci., 4: 229-236. DOI: 10.3844/jssp.2008.229.229
Hoque, M. and Y. Itohara, 2009. Women empowerment through participation in micro-credit programme: A case study from Bangladesh. J. Soc. Sci., 5: 244250. DOI: $10.3844 /$ jssp.2009.244.250

Islam, N. and N. Sultana, 2006. The status of women in Bangladesh: Is the situation really encouraging? Res. J. Soc. Sci., 1: 56-65.

Ogunlade, I. and S.A. Adebayo, 2009. Socio-economic status of women in rural poultry production in selected areas of Kwara State, Nigeria. Int. J. Poult. Sci., 8: 55-59.

Sarker, A.E. and M.H. Rahman, 2007. The emerging perspective of governance and poverty alleviation: A case of Bangladesh. Public Org. Rev., 7: 93-112. DOI: $10.1007 / \mathrm{s} 11115-006-0023-\mathrm{y}$

Ware, N., 2007. Impact of NGO programmes on rural women in Bangladesh. Asain Affairs, 29: 5-40. 